\title{
PELAKSANAAN UNDANG-UNDANG PERKAWINAN TAHUN 1974 Studi Perceraian dan Poligami di Kabupaten Enrekang MATTUGENGKENG
}

\section{I}

Eksistensi kehidupan rumah tangga dalam suatu kelompok masyarakat sesungguhnya berfariasi dan berkembang menurut kebutuhan masyarakat pendukungnya. Berfariasi karena kondisi sosial budaya serta kepercayaan masyarakatnya dan berkembang karena faktor kebutuhan masyarakat yang selalu berkembang.

Bagi bangsa Indonesia yang berdiam dalam beberapa pulau dan terdiri dari berbagai suku, adat istiadat dan kepercayaan, terbentuk pula beberapa ragam bentuk perkawinan sebagai wadah kehidupan berumah tangga.

Dengan terwujudnya beberapa ragam bentuk dan sistem dalam perkawinan ditengahtengah masyarakat, melahirkan pula pranatapranata sosial dalam masyarakat.

Adapun yang menjadi inti permaslahan dalam tulisan ini hanyalah pranata poligami dan cerai dalam kaitannya dengan pelaksanaan Undang-undang Nomor 1 Tahun 1974 Tentang Perkawinan. Bagaimana pelaksanaannya, sejauhmana pengaruhnya terhadap kehidupan sosial keagamaan masyarakat, dan bagaimana pandangan masyarakat terhadap undang-undang tersebut.

Hasil penelitian ini dilaksanakan dengan harapan kiranya dapatberguna dalam penyusunan kebijakan untuk pembinaan kwalitas keagamaan masyarakat terutama dalam pembinaan rumah tangga atau keluarga.

Pengumpulan data dilaksanakan di Kabupaten Enrekang dengan menetapkan lokasinya pada seluruh Wilayah Pemerintahan tingkat Kecamatan.

Rencana semua lokasi pengumpulan data akan dilaksanakan dalam satu kecamatan dengan menetapkan satu desa atau lebih untuk memperluas wawasan analisis, namun karena tidak diperoleh data yang refresentatif pada satu desa dalam wilayah kecamatan tertentu, maka sasaran penelitian ditetapkan kemudian sebagaimana tersebut diatas.

Untuk pengukuran sejauh mana pelaksanaan undang-undang perkawinan dan bagaimanan tanggapan masyarakat terhadap undang-undang perkawinan tersebut, khusus di kabupaten Enrekang sangat ideal bila diseluruh kecamatan dijadikan sasaran pengambilan data. Demikian pula nampaknya studi ini mendekati kajian dokumen karena sumber data yang perimer berasal dari dokumen-dokumen instansi pelaksanaan undang-undang sedang sumber data dari masyarakat nampaknya menjadi data yang sekunder.

Dalam pengumpulan data perimer dilaksanakan pada semua KantorUrusan Agama Kecamatan, Kantor agama tingkat kabupaten dan Kantor Pengadilan Agama Kabupaten Enrekang. Sementara pengumpulan dokumendokumen pada instansi-instansi tersebut diatas dilaksanakan pula wawancara dengan petugas yang menangani masalah-masalah yang menjadi obyek penelitian untuk mengetahui sejauh mana pelaksanaan undang-undang perkawinan, tatacara pelaksanaan serta suka dan duka yang dialami para petugas dalam melaksanakan tugas-tugasnya.

No. 1 \& 2 Thn. I Juli / Desember 1990 
Pengumpulan data yang bersumber dari masyarakat dilaksanakan dengan wawancara langsung dan tidak langsung.' Langsung dimaksud adalah wawancara yang dilaksanakan oleh peneliti secara langsung dengan para responden atau informan. Sedang yang dimaksud tidak langsung adalah wawancara yang berlangsung terhadap orang-orang tertentu yang dianggap banyak mengenal peribadi responden. Hal ini dilaksanakan mengingat bahwa kondisi masyarakat Enrekang masih sangat peka terhadap masalah yang dipelajari oleh peneliti.

Sebagai tahap akhir dalam penyusunan laporan penelitian ini penulis berusaha menyusun dengan tehnis diskriftif kwalitatif dengan pendekatan antropologis.

\section{II}

Kabupaten Derah Tingkat II Enrekang terletak ditengah-tengah dataran Sulawesi Selatan yang tidak mempunyai pantai danau dan laut. Daerah ini bergunung-gunung dengan ketinggian antara $500-700 \mathrm{~m}$ dari permukaan laut.

Secara administratip daerah ini terletak disebelah utara dengan Kabupaten Tana Toraja (TATOR) sebelah selatan dengan K bupaten Sidenreng Rappan (SIDRAP), sebelah timur dengan Kabupaten Luwu, dan disebelah barat dengan Kabupaten Pinrang.

Dari segi pembagian wilayah pemerintahan, maka Kabupaten Enrekang terbagi kendala lima Wilayah Pemerintahan Tingkat Kecamatan, 23 Wilayah Pedesaan termasuk enam diantaranya sebagai Kelurahan, 102 Dusun, 273 Organisasi Rukun Kampung (ORK) 757 Organisasi Rukun Tangga (ORT), 26651 rumah tangga, dan 139.256 jiwa penduduk.
Luas wilayah Kabupaten Enrekang $1.786,01 \mathrm{~km}^{2}$, dan rata-rata jumlah jiwa setiap kilometer 77, dan lima jiwa setiap rumah tangga.

Nmapkanya kesadaran masyarakat tentang pentingnya pendidikan cukup tinggi yang dibuktikan dengan banyaknya penduduk yang telah mengikuti pendidikan sekitar 67449 jiwa, 38969 jiwa tamat SD atau yang sederajat, 15435 jiwa tamat tingkat lanjutan pertama, 12340 jiwa tamat tingkat lanjutan atas, 479 jiwa tamat tingkat Akademi, dan 186 jiwa yang selesai pada tingkat Perguruan Tinggi.

Dikabupaten Enrekang tidak terdapat urbanisasi. Masyarakat menempatkan kota Enrekang (ibukota Kabupaten Enrekang) sebagai pfusat kegiatan pemerintahan semata, bukan sebagai pusat segala kegiatan masyarakat, sedang untuk kegiatan kebutuhan masyarakat lainnya masing-masing kecamatan telah mampu meladeni masyarakat.

Mata pertanian yang rata-rata petani pemilik dengan jumlah 29336 jiwa kemudian sektor perdagangan 1039 jiwa, industri kecil 469 jiwa, pertukangan 561 jiwa.

Kegairahan masyarakat ikut serta dalam pendidikan yang mengarah pada pengembangan beragama, baik pada pendidikan formal di sekolah-sekolah maupun pada pendidikan non formal dibeberapa tempat tertentu, cukup tinggi, ternyata pendidikan formal cukup banyak yaitu untuk tingkat ibtidaiyah 22 buah Tsanawiyah 18 buah dan Aliah sembilan buah dan pendidikan non formal yaitu pengajian Alqur'an terdapat 141 buah dengan jumlah peserta 2921 laki-laki, 2936 wanita jumlah keseluruhan 5677 orang.

Pelaksanaan jamaah Jum'at maupun shalat wajib lainnya seperti ; Shalat Subuh, Magrib dan Isya dimeriahkan oleh masyarakat dengan 
jumlah jamaah setiap kali shalat dalam setiap mesjid cukup ramai, sedang jumlah mesjid, mushallah, dan langgar yang memadai yaitu mesjid 285 buah mshallah 10 buah dan langgar 95 buah sedang jumlah penduduk keseluruhan 139,256. jiwa.

$\mathrm{m}$

Masalah poligami dalam masyarakat Enrekang ternyata tidak banyak, baik sebelum undang-undang perkawinan maupun sesudahnya. Kecenderungan masyarakat untuk beristeri lebih dari satu pada hakekatnya tidak ada, namun tetap terjadi dalam masyarakat karena faktor-faktor tertentu.

Tercatat pada Kantor Pengadilan Agama Kabupaten Enrekang dari tahun 1984 - 1989 hanya terdapat tiga orang yang memperoleh rekomendasi yang di isinkan untuk melakukan poligami, walaupun dalam masyarakat kasus poligami bukan hanya tiga orang.

Hal tersebut diatas menunjukan bahwa dalam masyarakat Enrekang terdapat dua bentuk poligami yaitu ; poligami yang direncanakan dan yang direstui oleh pemerintah dan poligami yang karena terpaksa.

Kebebasan dalam pergaulan antara perempuan dan laki-laki adalah faktor dominan yang mewujudkan poligami. Poligami yang dimaksud bukan yang mendapat despensasi dari pemerintah, tetapi yang tidak diketahui oleh pihak pemerintah.

Ada beberapa responden yang beranggapan bahwa kurangnya poligami dalam masyarakat di Enrekang karena inkam masyarakat sangat rendah yakni untuk tahun 1988 baru mencapai Rp. 13.000,- perbulan setiap orang. Ternyata orang yang perpoligami dalam masyarakat Enrekang bukan yang kaya saja tetapi ekonomi rendah juga banyak yang terlibat.
Penyebab poligami nampaknya bukan terletak pada kaya atau miskinnya seseorang, akan tetapi tergantung pada mampu atau tidaknya seseorang mengendalikan syahwatnya.

Selain poligami, juga cerai merupakan salah satu akibat negatif dari perkawinan. Perilaku cerai sesungguhnya tabu bagi masyarakat, namun masalahnya cerai ini tetap pula berlangsung ditengah-tengah masyarakat penantangnya, dan kadang-kadang ada orang yang dengan mudah melaksanakannya.

Dalam masalah proses terjadiinya suatu pemisahan antara seorang suami dengan isterinya di bedakan antara talak dengan cerai. Perbedaannya dimaksudkan dari segi perosedur terjadinya perceraian. Perbedaan yang dimaksudkan dari segi perosudur terjadi perceraian. Jika perceraian itu terjadi karena permohonan talak bersumber dan diajukan oleh pihak suami terhadap isterinya dikenal dengan istilah ikrar talak, akan tetapi gugatan datangnya dari pihak isteri terhadap suaminya disebut gugatan cerai (fasah) dan Taklik Talak. Adapun bentuk ke tiga dari perceraian adalah gugatan yang bersumber dari kedua suami isteri di sebut Syiqak atau khuluk.

Ternyata talak di Kabupaten Enrekang lebih banyak dari pada cerai yang untuk tahun 1988/ 1989 terdapat 30 talak sedang cerai hanya 19 kasus. Dan untuk lima tahun terakhir yaitu 1984 - 1988 talak sejumlah 147 kasus dan cerai sejumlah 99 kasus.

Alasan-alasan terjadinya perselisihan yang diahiri dengan perceraian bagi masyarakat enrekang nampaknya didominasi oleh unsurunsur ; pihak lain selama-lamanya, kemudian alasan biologi ditinggalkan oleh politis dan krisis ekonomi

Alasan-alasan terjadinya perselisihan dan kemudian diahiri dengan perceraian bagi masyarakat Enrekang nampaknya kebanyakan

No. 1 \& 2 Thn. I Juli / Desember 1990 
karena alasan perantauan atau meninggalkan satu dengan yang lainnya selama-lamanya, kemudian karena alasan biologi, menyusul karena andalan ekonomi dan politik dan selanjutnya karena pergaulan suami isteri yang selalu pincang.

Diperoleh data pada Kantor Pengadilan Agama Kabupaten Enrekang angka-angka mengenai alasan-alasan terjadinya perceraian masing-masing untuk meninggalkan pihak lain selama-lamanya 38 pasang, alasan biologi 14 pasang politis dan kerisis ekonomi masingmasing tujuh pasang, pergaulan suami isteri yang bentrok lima pasang dan masalah cemburu, perpihak ketiga dua orang (untuk tahun 1988 - 1989).

Bagi masyarakat Enrekang mengenai suatu perinsip bahwa perselisihan yang terjadi dikalangan masyarakat diselesaikan lewat meja hijau (perkara di pengadilan) pantang untuk rukun kembali. Nampaknya setiap kasus yang sampai kepengadilan atau ke BP 4 tingkat kabupaten tidak pernah berhasil untuk dipulihkan. Apalagi ditingkat banding, pihak yang kalah tidak pernah mengajukan permohonan banding di Pengadilan Tinggi Agama di Ujung Pandang.

\section{IV}

Pihak pemerintah dalam hal ini Departe- men Agama sebagai pelaksanaan utama undang-undang perkawinan, khususnya di Kabupaten Enrekang telah berusaha untuk memperkanalkan undang-undang perkawinan secara pormal maupun tidak formal.

Formal dimaksudkan disini adalah pemasyarakatan undang-undang dengan langsung melayani masyarakat dengan peraktis. Sedang tidak langsung dimaksud adalah pemasyarakatan undang-undang perkawinan lewat penyuluhan, media dakwa melalui mimbar agama dan penerangan secara umum.

Adapun mengenai tanggapan masyarakat terhadap undang-undang perkawinan ini sudah positif, walaupun dalam masyarakat seakan-akan kenyataannya menempatkan instansi pelaksanaan undang-undang sebagai legimitasi, belum sebagai lembaga penasehat atau pembimbing yang mengarahkan masyarakat kejenjang kehidupan rumah tangga yang tenteram dan damai.

Ternyata dalam setiap kasus yang terjadi di masyarakat lebih banyak dipulihkan kembali menjadi rukun dan damai oleh pihak keluarga masing-masing kedua belah pihak yang berselisih dari pada upaya yang dilaksanakan oleh pihak pemerintah. Khusus di Kabupaten Enrekang selama lima tahun terakhir ini tidak ditemukan data yang menunjukan pengembalian keharmonisan rumah tangganya.

No. 1 \& 2 Thn. I Juli / Desember 1990 
Pelaksanaan Undang-Undang Perkawinan Tahun 1974

Studi Perceraian dan Poligami di Kabupaten Enrekang

\section{DAFTAR BACAAN}

1. Al, Attar, Abu Nasir Taufiq, Dr. POLIGAMI, ditinjau dari segi sosial dan perundang-undangan, Bulan BIntang, Jakarta, 1976.

2. ENREKANG DALAM ANGKA, 1987 1988, Kantor statistik Kab. Enrekang.

3. LAPORAN TAHUN AN KEGIATAN tahun 1988/1989, Kantor Departemen Agama Kabupaten Enrekang.
4. PENDAPATAN REGIONAL KABUPATEN ENREKANG, 1983 - 1987, Kantor Statistik Kabupaten Enrekang.

5. PEDOMAN BERACARA PADAPENGADILAN AGAMA, Direktorat Pembinaan Badang Peradilan Agama, Departemen Agama, Jakarta 1980 - 1988. 